\title{
IMPLEMENTASI ALGORITMA BRUTE FORCE DALAM PENCARIAN KEBUDAYAAN DI INDONESIA BERB ASIS MOBILE APPLICATION
}

\author{
Sugiharto, S.Kom \\ sugiharto@gmail.com
}

Perkembangan teknologi informasi yang sedemikian cepatnya telah membawa dunia memasuki era baru yang lebih cepat. Salah satu hasil dari kemajuan teknologi adalah dihasilkannya teknologi perangkat mobile. Teknologi perangkat mobile saat ini sudah semakin berkembang penggunaannya seiring dengan perkembangan zaman, dimana salah satunya adalah perkembangan komunikasi berbasis mobile smartphone. Teknologi yang menjadi pengaruh sangat besar saat ini adalah platform smartphone berbasis android. Salah satu manfaat smartphone berbasis android yang dapat di gunakan yaitu untuk mencari berbagai informasi atau ilmu pengetahuan dengan mudah dan cepat.

Informasi mengenai kebudayaan di Indonesia saat ini sangat di butuhkan agar pengguna atau generasi muda dapat mengenal dan melesetarikan kebudayaan Indonesia ataupun kebudayaan di daerahnya sendiri dengan mudah. Seiring berkembangnya zaman, menimbulkan perubahan pola hidup masyrakat yang lebih modern terutama bagi remaja sebagai generasi muda. Akibatnya, masyarakat lebih memilih kebudayaan baru seperti kebudayaan asing yang mungkin dinilai lebih praktis dibandingkan dengan budaya lokal. Budaya asing masuk ke Indonesia membawa berbagai macam pengaruh, yaitu pengaruh positif dan pengaruh negatif. Salah satu contoh yang dapat dilihat dari sisi negatif kebudayaan asing yang datang ke Indonesia adalah gaya hidup orang asing, mulai dari cara berpakaian kurang sopan yang seharusnya tidak digunakan sampai dengan cara bergaul mereka. Hal ini tidak dapat dibiarkan begitu saja sebagai generasi penerus bangsa sudah semestinya menjaga dan melestarikan kebudayaan Indonesia. Dalam hal ini, mengenal budaya Indonesia saja sangatlah penting karena mengenal budaya dan keanekaragaman Indonesia adalah salah satu awal yang baik untuk kita nantinya akan melestarikan keanekaragaman budaya Indonesia.

Berdasarkan uraian di atas, penulis akan memanfaatkan teknologi perangkat mobile smartphone berbasis android untuk membangun aplikasi pencarian informasi kebudayaan yang terdapat di indonesia. Dengan menggunakan perangkat mobile yang dapat di bawa kemana saja, maka pengguna di mudahkan untuk mencari informasi kebudayaan di indonesia dengan mudah dan cepat. Untuk membangun aplikasi pencarian kebudayaan di Indonesia yang berbasis mobile, maka dalam penelitian ini penulis akan menggunakan algoritma brute force. Algoritma brute force ini akan di terapkan dalam proses pencarian kebudayaan di indonesia, dimana algoritma ini dapat di gunakan dalam pencarian string atau teks.

Kata Kunci : Brute Force, Mobile Phone, Android,

The rapid development of information technology has brought the world into a new era that is faster. One result of technological advances is the production of mobile device technology. Today's mobile device technology has increasingly developed along with the times, one of which is the development of mobile smartphone-based communications. Technology that is a huge influence now is an Android-based smartphone platform. One of the benefits of an Androidbased smartphone that can be used is to find various information or knowledge easily and quickly. Information about culture in Indonesia is currently urgently needed so that users or the younger generation can easily recognize and capture Indonesian culture or culture in their own area. As the times evolved, it caused changes in the lifestyle of the more modern society, especially for teenagers as the younger generation. As a result, people prefer new cultures such as foreign cultures that might be considered more practical than local cultures. Foreign cultures entering Indonesia carry a variety of influences, namely positive influences and negative influences. One example that can be seen from the negative side of foreign culture that comes to Indonesia is the lifestyle offoreigners, ranging from irreverent ways of dressing that should not be used to how to get along with them. This cannot be left alone as the next 
generation of the nation should preserve and preserve Indonesian culture. In this case, just knowing Indonesian culture is very important because knowing the culture and diversity of Indonesia is one of the good beginnings for us to later preserve the diversity of Indonesian culture.Based on the description above, the author will utilize the Android-based smartphone mobile technology to build a cultural information search application found in Indonesia. By using a mobile device that can be carried anywhere, users are easily made to search for cultural information in Indonesia easily and quickly. To build a culture-based search application in Indonesia, in this study the writer will use a brute force algorithm. This brute force algorithm will be applied in the process of finding culture in Indonesia, where this algorithm can be used in string or text searches.

Keywords: Brute Force, Mobile Phone, Android,

\section{PENDAHULUAN}

Perkembangan teknologi informasi yang sedemikian cepatnya telah membawa dunia memasuki era baru yang lebih cepat. Salah satu hasil dari kemajuan teknologi adalah dihasilkannya teknologi perangkat mobile. Teknologi perangkat mobile saat ini sudah semakin berkembang penggunaannya seiring perkembangan zaman, dimana salah satunya adalah perkembangan komunikasi berbasis mobile smartphone. Teknologi yang menjadi pengaruh sangat besar saat ini adalah platform smartphone berbasis android. Salah satu manfaat smartphone berbasis android yang dapat di gunakan yaitu untuk mencari berbagai informasi atau ilmu pengetahuan dengan mudah dan cepat.

Informasi mengenai kebudayaan di Indonesia saat ini sangat di butuhkan agar pengguna atau generasi muda dapat mengenal dan melesetarikan kebudayaan Indonesia ataupun kebudayaan di daerahnya sendiri dengan mudah. Seiring berkembangnya zaman, menimbulkan perubahan pola hidup masyrakat yang lebih modern terutama bagi remaja sebagai generasi muda. Akibatnya, masyarakat lebih memilih kebudayaan baru seperti kebudayaan asing yang mungkin dinilai lebih praktis dibandingkan dengan budaya lokal. Budaya asing masuk ke Indonesia membawa berbagai macam pengaruh, yaitu pengaruh positif dan pengaruh negatif. Salah satu contoh yang dapat dilihat dari sisi negatif kebudayaan asing yang datang ke Indonesia adalah gaya hidup orang asing, mulai dari cara berpakaian kurang sopan yang seharusnya tidak digunakan sampai dengan cara bergaul mereka. Hal ini tidak dapat dibiarkan begitu saja sebagai generasi penerus bangsa sudah semestinya menjaga dan melestarikan kebudayaan Indonesia. Dalam hal ini, mengenal budaya Indonesia saja sangatlah penting karena mengenal budaya dan keanekaragaman Indonesia adalah salah satu awal yang baik untuk kita nantinya akan melestarikan keanekaragaman budaya Indonesia.

Berdasarkan uraian di atas, penulis akan memanfaatkan teknologi perangkat mobile smartphone berbasis android untuk membangun aplikasi pencarian informasi kebudayaan yang terdapat di indonesia. Dengan menggunakan perangkat mobile yang dapat di bawa kemana saja, maka pengguna di mudahkan untuk mencari informasi kebudayaan di indonesia dengan mudah dan cepat.

Untuk membangun aplikasi pencarian kebudayaan di Indonesia yang berbasis mobile, maka dalam penelitian ini penulis akan menggunakan algoritma brute force. Algoritma brute force ini akan di terapkan dalam proses pencarian kebudayaan di indonesia, dimana algoritma ini dapat di gunakan dalam pencarian string atau teks. Berdasarkan latar belakang masalah diatas, maka penulis melakukan penelitian dengan judul "Implementasi Algoritma Brute Force Dalam Pencarian Kebudayaan Di Indonesia Berbasis Mobile Application.

Dari latarbelakang diatas, maka dapat diketahui rumusan masalah sebagai berikut :

1. Bagaimana merancang dan membangun suatu aplikasi pencarian yang mampu menyediakan informasi mengenai kebudayaan di indonesia dengan menggunakan perangkat bergerak (mobile device) berbasis android ?

2. Bagaimana mengimplementasikan algoritma brute force untuk pencarian kebudayaan di Indonesia dengan menggunakan bahasa pemrograman java berbasis android? 
3. Bagaimana cara agar user dapat dengan mudah mencari informasi tentang kebudayaan di Indonesia berdasarkan kategori yang tersedia?.

Batasan masalah dalam penelitian ini adalah:

1. Aplikasi ini membahas informasi mengenai kebudayaan dari 34 provinsi di indonesia.

2. Sumber referensi dari buku "Mengenal Seni dan Budaya Indonesia" oleh R. Rizky dan T. Wibisono..

3. Aplikasi yang akan di bangun menggunakan algoritma brute force dalam proses pencarian kebudayaan di indonesia.

4. Aplikasi pencarian kebudayaan di Indonesia berdasarkan kategori pilihan seperti rumah adat, pakaian adat, senjata tradisional dan alat musik.

5. Pembangunan aplikasi pencarian kebudayaan di Indonesia menggunakan bahasa pemrograman java berbasis android sebagai client dan bahasa pemrograman PHP di sisi server.

6. Database yang di gunakan dalam pembangunan aplikasi pencarian kebudayaan di Indonesia yaitu menggunakan MySQL.

\section{METODELOGI PENELITIAN}

\subsection{Metode Pengembangan Sistem}

Metodologi pengembangan yang digunakan dalam perancangan aplikasi perangkat lunak ini menggunakan metodologi kerja Relational Unified Process (RUP). Relational Unified Process $(R U P)$ adalah pendekatan perangkat lunak yang dilakukan berulang-ulang (iterative), fokus pada arsitektur (architecturecentric), lebih diarahkan berdasarkan penggunaan kasus (use case driven). RUP merupakan proses rekayasa perangkat lunak dengan pendefinisian yang lebih baik (well defined) dan penstrukturan yang baik (well structured). RUP menyediakan pendefinisian yang baik untuk alur hidup proyek perangkat lunak:

RUP memiliki 4 tahap atau fase yang dapat dilakukan pula secara iterative, berikut adalah penjelasan untuk setiap fase RUP :

\section{Inception}

Tahap ini lebih pada memodelkan proses bisnis yang dibutuhkan (business modeling) dan mendefinisikan kebutuhan akan
p-ISSN : 2527-4856, e-ISSN : 2614-5413

https://journal.uniku.ac.id/index.php/buffer

sistem yang akan dibuat (requirements).

\section{Elaboraion}

Tahap ini lebih pada analisis dan desain sistem serta implementasi sistem yang fokus pada purwarupa sistem (prototype).

\section{Construction}

Tahapan ini lebih pada implementasi dan pengujian sistem yang fokus pada implementasi perangkat lunak pada kode program.

4. Transition

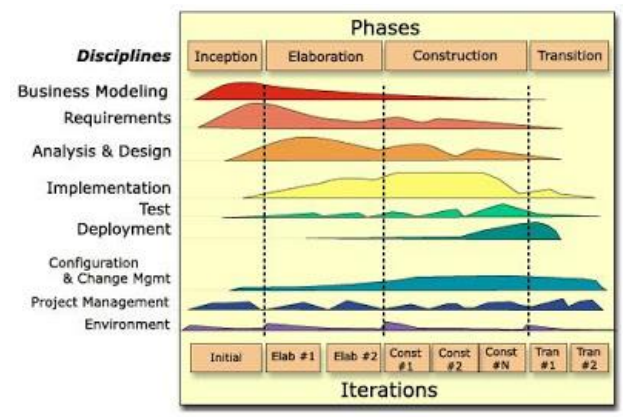

Gambar 1. Gambar Fase RUP

\subsection{Teknik Pengumpulan Data}

Metode yang di gunakan untuk mengumpulkan data dan informasi yang di perlukan dalam penelitian ini adalah studi literature. Dalam tahap studi literature ini dilakukan dengan membaca dan mempelajari lebih dalam buku- buku referensi, jurnal atau sumber - sumber penelitian lain yang berkaitan dengan kebudayaan di Indonesia serta teori algoritma brute force.

\section{HASIL DAN PEMBAHASAN 3.1 Analisis Sistem yang Diusulkan}




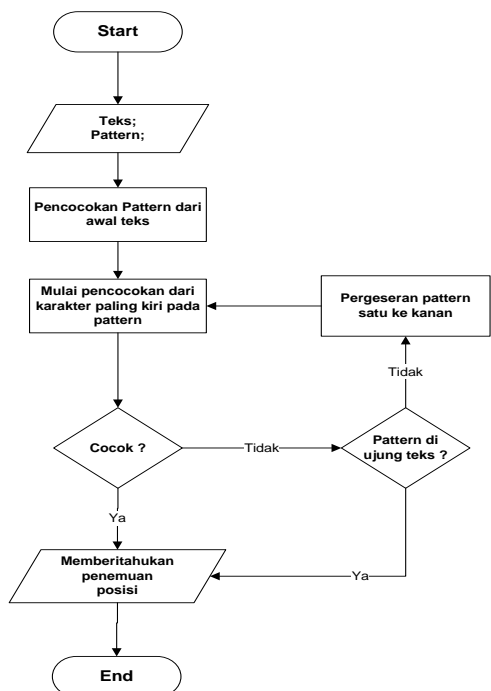

Gambar 2. Flowchart Algoritma Brute Force

\subsection{Perancangan Use Case Diagram}

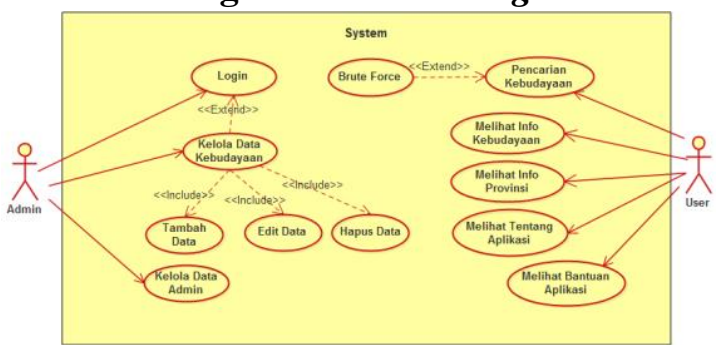

Gambar 3. Use case diagram sistem Pada gambar 3 use case diagram akan di deskripsikan sebagai berikut :

\subsection{Activity Diagram}

Diagram activity akan menampilkan aliran kerja atau aktivitas dari sebuah sistem yang ada pada aplikasi. Di mana aktivitas ini akan menggambarkan aktivitas sistem dan bukan yang di lakukan oleh aktor terhadap aplikasi, jadi activity diagram ini akan menampilkan aktivitas-aktivitas yang dilakukan oleh system.

\section{a. Activity Diagram Login}

p-ISSN : 2527-4856, e-ISSN : 2614-5413

https ://journal.uniku.ac.id/index.php/buffer

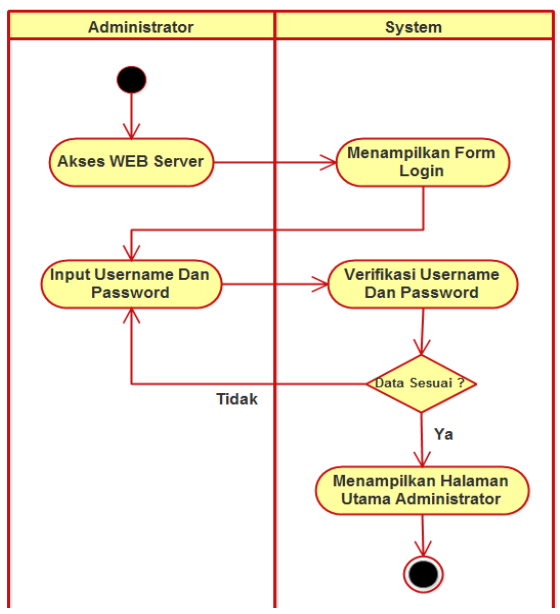

Gambar 4. Activity diagram Login

b. Activity Diagram tambah data kebudayaan

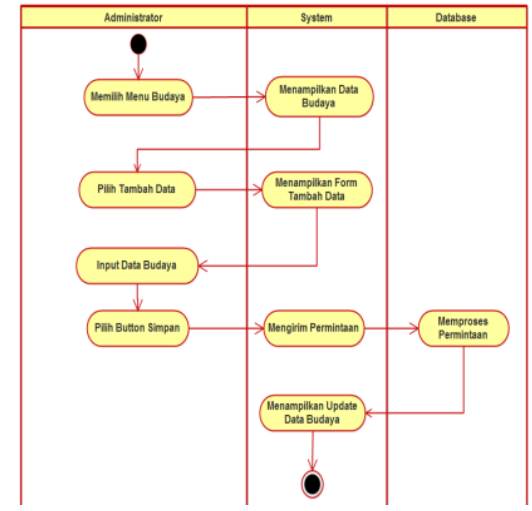

Gambar 5. Activity diagram tambah data kebudayaan

c. Activity Diagram Pencarian data kebudayaan

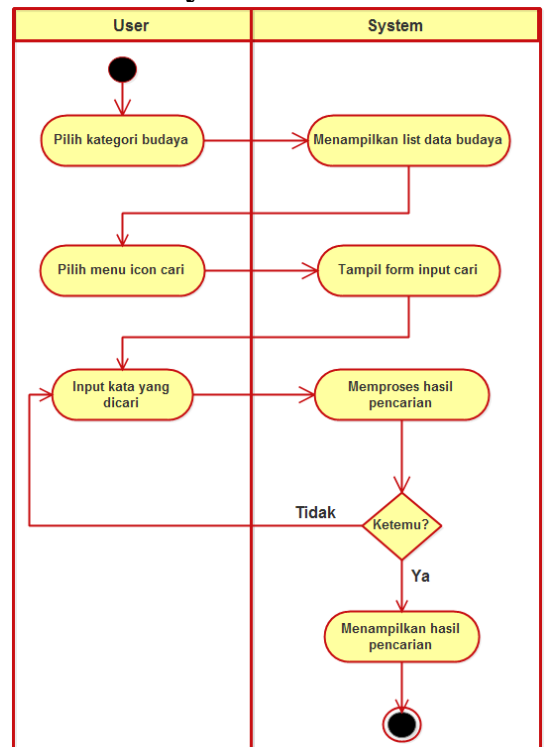

Gambar 6. Activity diagram presensi

\subsection{Class Diagram}


JURNAL BUFFER INFORMATIKA

Volume 4 Nomor 2, Oktober 2018

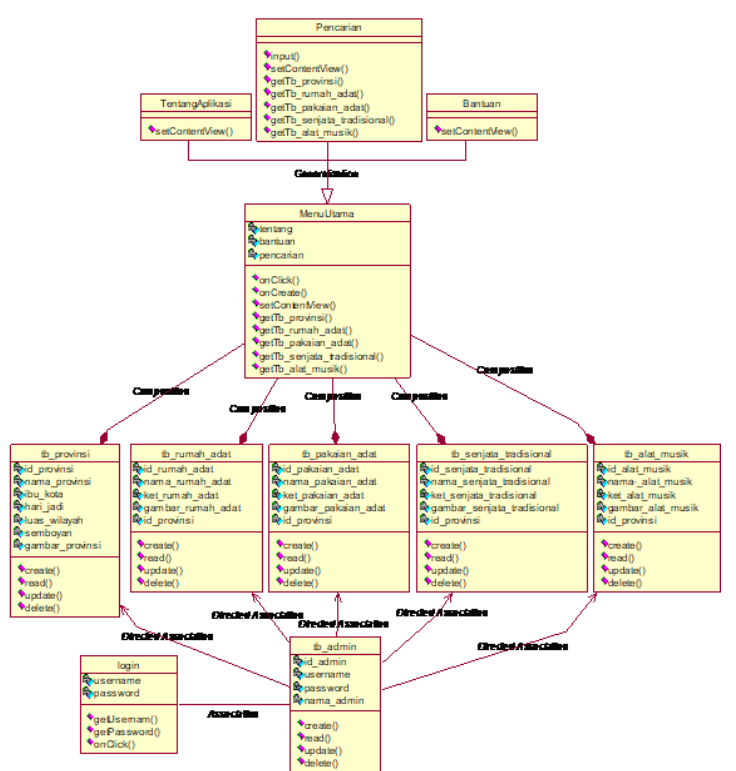

Gambar 7. Class Diagram

\subsection{Sequence Diagram}

\section{a. Sequence Diagram Login}

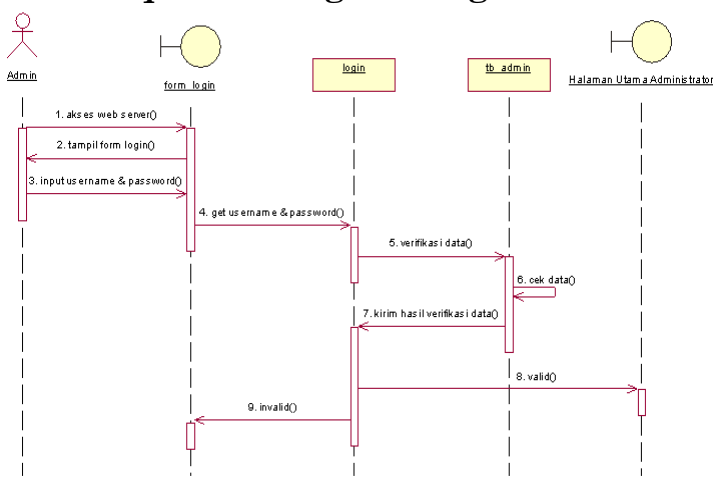

Gambar 8. sequence diagram Login

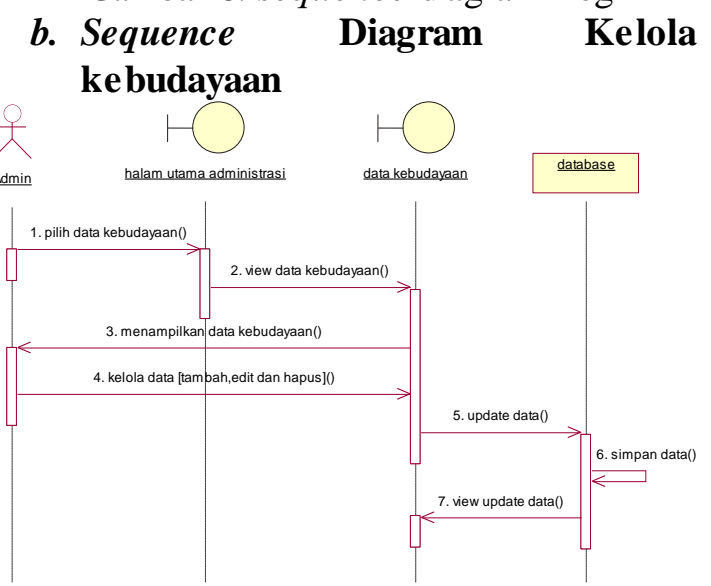

Gambar 9. Sequence diagram Kelola Data
c. Sequence
kebudayaan

Diagram
p-ISSN : 2527-4856, e-ISSN : 2614-5413

https ://journal.uniku.ac.id/index.php/buffer

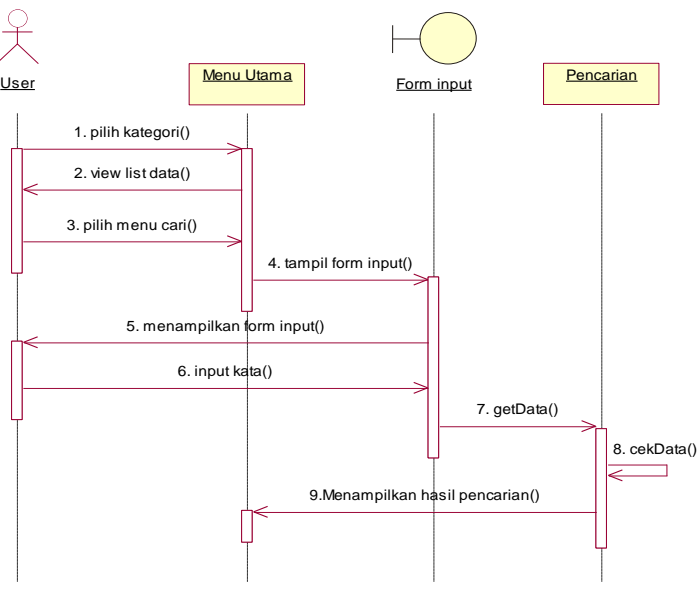

Gambar 10. Sequence pencarian kebudayaan 3.6 Construction

Setelah mengalami sederetan proses iterasi, pada tahapan Construction ini sudah dapat menghasilkan suatu aplikasi. Hasil dari aplikasi yang sudah dirancang dapat dilihat pada tampilan Gambar berikut :

1. Halaman Utama Aplikasi

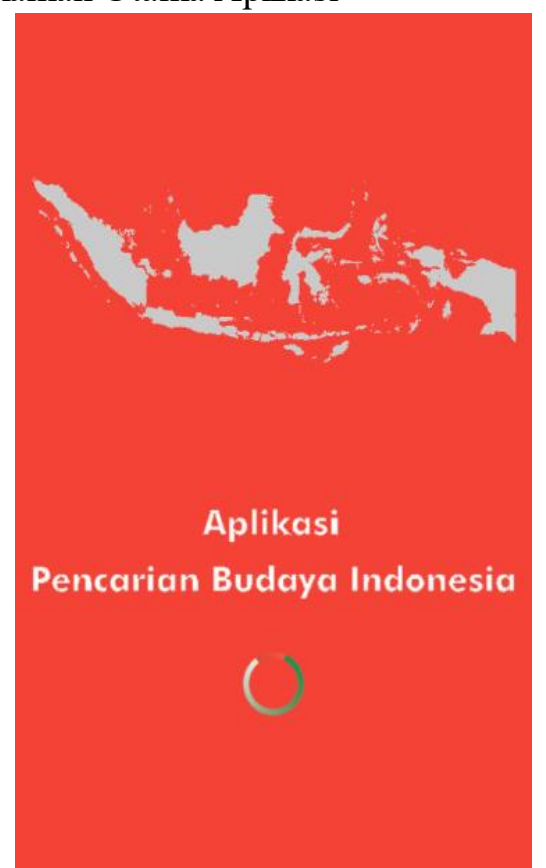

Gambar 11. Halaman Utama Aplikasi

2. Halaman utama 
JURNAL BUFFER INFORMATIKA

Volume 4 Nomor 2, Oktober 2018

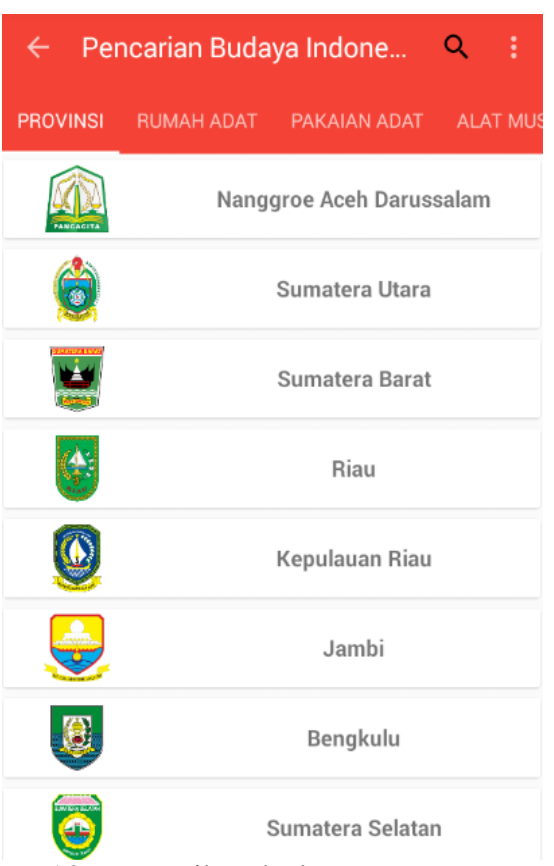

Gambar 12. Tampilan halaman utama.

\section{Halaman Menu pencarian}
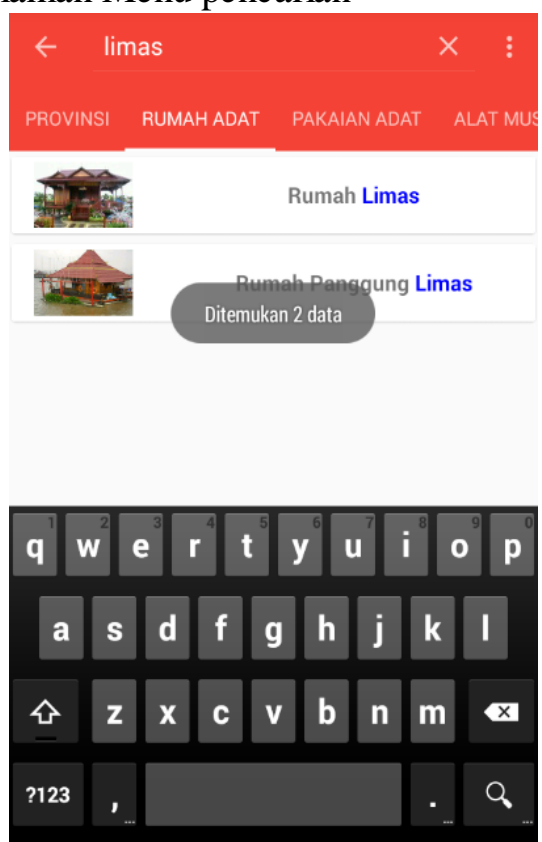

Gambar 13. Halaman pencarian

\subsection{Pengujian Pe rangkat Lunak}

Pengujian black box adalah proses pengujian aspek fundamental aplikasi tanpa memperhatikan struktur logika internal perangkat lunak. Proses pengujian ini dilakukan untuk mengetahui apakah aplikasi perangkat lunak dapat berjalan dan berfungsi dengan benar.
p-ISSN : 2527-4856, e-ISSN : 2614-5413

https ://journal.uniku.ac.id/index.php/buffer

1. Pengujian Black Box

Tabel 1.Hasil Pengujian Black Box

\begin{tabular}{|c|c|c|c|c|}
\hline \multirow{2}{*}{$\begin{array}{l}\mathrm{N} \\
\mathrm{o}\end{array}$} & \multirow{2}{*}{ Skenario } & \multicolumn{2}{|c|}{$\begin{array}{c}\text { Hasil } \\
\text { Pengujian } \\
\end{array}$} & \multirow{2}{*}{ Keterangan } \\
\hline & & $\begin{array}{l}\text { Dite } \\
\text { rima }\end{array}$ & $\begin{array}{l}\text { Dito } \\
\text { lak }\end{array}$ & \\
\hline 1 & $\begin{array}{lr}\text { Login } & \text { dengan } \\
\text { username } & \text { dan } \\
\text { password } & \text { yang } \\
\text { benar. } & \end{array}$ & $\sqrt{ }$ & & $\begin{array}{l}\text { Berhasil masuk } \\
\text { halaman utama } \\
\text { administrator. }\end{array}$ \\
\hline 2 & $\begin{array}{lr}\text { Login } & \text { dengan } \\
\text { username } & \text { dan } \\
\text { password } & \text { yang } \\
\text { salah. } & \end{array}$ & $\sqrt{ }$ & & $\begin{array}{l}\text { Muncul pesan } \\
\text { kesalahan } \\
\text { "username atau } \\
\text { password salah !" }\end{array}$ \\
\hline 3 & $\begin{array}{lr}\text { Tidak } & \text { mengisi } \\
\text { form } & \text { login } \\
\text { kemudian } & \mathrm{di} \\
\text { submit. } & \end{array}$ & $\sqrt{ }$ & & $\begin{array}{l}\text { Muncul pesan } \\
\text { kesalahan } \\
\text { "username atau } \\
\text { password salah!" }\end{array}$ \\
\hline 4 & Klik semua menu. & $\sqrt{ }$ & & Berhasil di buka. \\
\hline 5 & $\begin{array}{l}\text { Menampilkan } \\
\text { data. }\end{array}$ & $\sqrt{ }$ & & $\begin{array}{l}\text { Data berhasil di } \\
\text { tampilkan. }\end{array}$ \\
\hline 6 & $\begin{array}{l}\text { Menambahkan } \\
\text { data baru. }\end{array}$ & $\sqrt{ }$ & & $\begin{array}{l}\text { Data baru berhasil } \\
\text { di tambahkan. }\end{array}$ \\
\hline 7 & $\begin{array}{l}\text { Mengubah data } \\
\text { y ang sudah ada. }\end{array}$ & $\sqrt{ }$ & & $\begin{array}{l}\text { Data berhasil di } \\
\text { ubah. }\end{array}$ \\
\hline 8 & Menghapus data. & $\sqrt{ }$ & & $\begin{array}{l}\text { Data berhasil di } \\
\text { hapus. }\end{array}$ \\
\hline
\end{tabular}

\section{Pengujian White Box}

Pengujian White Box Testing dapat dilakukan sebagai berikut :

a. $\mathrm{V}(\mathrm{G})=\mathrm{E}-\mathrm{N}+2$ hasilnya sama dengan $\mathrm{V}(\mathrm{G})=\mathrm{P}+1$

b. Flowgraph mempunyai region yang sama dengan jumlah V(G)maka sistem dikatakan sudah terbukti efektif dan efisien.

\section{Flow Graph Nation}

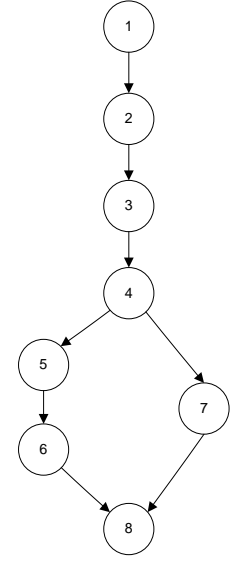

Gambar 14. Flow Graph Nation

Keterangan :

$\mathrm{V}(\mathrm{G})=$ Cyclomatic Complexity

$\mathrm{E} \quad=$ Jumlah edge pada grafik alir 
JURNAL BUFFER INFORMATIKA

Volume 4 Nomor 2, Oktober 2018

$\mathrm{N} \quad=$ Jumlah node pada grafik alir

Dapat dihitung cyclomatic complexity, yaitu sebagai berikut :

$\mathrm{E}=8, \quad \mathrm{~N}=8$

$\mathrm{V}(\mathrm{G})=\mathrm{E}-\mathrm{N}+2$

$$
\begin{aligned}
& =8-8+2 \\
& =2
\end{aligned}
$$

\section{Independent Path}

Dari hasil perhitungan cyclomatic complexity terdapat 2 independent path, yaitu:

Path $1: 1-2-3-4-5-6-8$

Path $2: 1-2-3-4-7-8$.

\section{KESIMPULAN}

1. Dengan menggunakan aplikasi ini dapat memberikan informasi kepada pengguna mengenai informasi kebudayaan yang berada di provinsi indonesia.

2. Penerapan algoitma brute force pada aplikasi pencarian kebudayaan di indonesia dapat menyelesaikan masalah dalam melakukan pencarian data budaya, karena algoritma ini menemukan data yang dicari.

3. Aplikasi yang dibangun terdapat pencarian (searching) data kebudayaan di indonesia, sehingga dapat memudahkan user dalam mencari data kebudayaan di indonesia.

\section{Saran}

Tentunya aplikasi ini masih jauh dari kata sempurna dan masih memiliki banyak kekurangan. Untuk itu, perlu dilakukan pengembangan dan penyempurnaan lebih lanjut. Adapun saran agar aplikasi ini bisa berjalan dengan lebih optimal dan lebih menarik, yaitu sebagai berikut :

1. Menambahkan beberapa kategori data budaya lagi, sehingga data budaya yang di cari lebih lengkap.

2. Penambahan fitur-fitur lain untuk lebih lengkap dalam mendukung aplikasi agar mempermudah user dalam memperoleh informasiinformasi yang berhubungan dengan budaya lainnya.

3. Aplikasi ini hanya dapat berjalan pada satu platform yaitu android. Kelemahan ini menjadi acuan untuk
p-ISSN : 2527-4856, e-ISSN : 2614-5413

https ://journal.uniku.ac.id/index.php/buffer

dapat dikembangkan lagi agar dapat digunakan di beberapa platform seperti iOS.

\section{DAFTAR PUSTAKA}

A.S, Rosa dan M. Salahuddin. (2015). Rekayasa Perangkat Lunak Terstruktur dan Berorientasi Objek. Bandung : Informatika Bandung

A.S, Rosa. (2011). Modul Pembelajaran Rekayasa Perangkat Lunak. Bandung : Modula

Aditya, F. dan Handoyo, E. (2011). "Perbandingan Paid Hosting dan Free Hosting Berdasarkan Fasilitas Backup yang ada", Jurnal Teknologi, VOL.4, NO. 1, JUNI 2011, h. 1-5.

Akhmad, Dharma Kasman. (2015). Aplikasi Pemesanan Tiket Online Berbasis Web \& PHP.

Aladag, C. H. and Hocaoglu, G. (2007). A Tabu Search Algorithm to Solve A Course Timetabling Problem. Haccettepe Journal of Mathematics and Statistics Volume 36 (1) (2007), 53-64.

Cirebon : CV. ASFA Solution

Coad, Peter and Yourdon, Edward. ObjectOriented Analysis, Yourdon Press, 1991.

Coad, Peter and Yourdon, Edward. ObjectOriented Design Second Edition, Yourdon Press. 1991.

Fatansyah, Ir. (2007).”Basis Data”. Bandung: Informatika Bandung.

Fowler, Martin.UML Distiled: Panduan Singkat Bahasa Pemodelan Object Standar, Edisi 3, Penerbit Andi: Yogyakarta. 2004.

Kruchten, Philippe, The Rational Unified Process An Introduction, Second Edition, John Wiley and Son Ltd. 2006.

Nugroho Adi.Rekayasa Perangkat Lunak Berorientasi Objek dengan metode USDP (Unified Software Development Process),Penerbit Andi:Yogyakarta. 2010.

Nugroho.Adi. 2009. Rekayasa Perangkat Lunak Menggunakan UML \& Java. Yogyakarta: Andi Offset;

Pressman, Roger S. (2007). Rekayasa Perangkat Lunak: pendekatan praktisi (Buku1). Beizer, B. (1995). Black-Box Testing, Wiley. Yogyakarta: Andi. 
JURNAL BUFFER INFORMATIKA

Volume 4 Nomor 2, Oktober 2018

Remick, Jarel. (2011). What Is a Web App? Here's Our Definition, http://web.appstorm.net, dilihat 17 Mei 2017;
p-ISSN : 2527-4856, e-ISSN : 2614-5413

https ://journal.uniku.ac.id/index.php/buffer 